\title{
Silence and Blindness in Richard Wright's Native Son
}

\author{
Chibuzo Onunkwo (Corresponding author) \\ Department of English and Literary Studies, University of Nigeria, Nsukka, Nigeria \\ E-mail: chibuzo.onunkwo@unn.edu.ng \\ Mary .J.N .Okolie \\ Department of English and Literary Studies, University of Nigeria, Nsukka, Nigeria \\ E-mail: Mary.okolie@unn.edu.ng \\ Chigbu,Andrew chigbu \\ Department of English and Literary Studies, University of Nigeria, Nsukka, Nigeria \\ E-mail: Andrew.chigbu@unn.edu.ng \\ Ginikachi Christian Uzoma \\ Department of English and Literary Studies, University of Nigeria, Nsukka, Nigeria \\ E-mail: ginikachi.uzoma@unn.edu.ng
}

Received: 19-02-2017

Accepted: 24-04-2017

Advance Access Published: July 2017

Published: 01-09-2017

doi:10.7575/aiac.ijalel.v.6n.5p.107

URL: http://dx.doi.org/10.7575/aiac.ijalel.v.6n.5p.107

\begin{abstract}
Richard Wright's Native Son has often been read as a socially-oriented text, seemingly neglecting its existence as a literary construct. Such readings gear towards identifying the text with such societal ills as racism and environmental impact on the individual, as if these are the only business of the text.In this paper, however, attention shifts from such external referents to the text itself, deconstructing the meaning of blindness already ascribed to the text as well as the meaning of silence as it is denotatively known. The uncovering of the textual meaning of each of these concepts will also serve either to compliment a character or to disparage same, and then the interweave of both concepts will result in reading the text as a tragedy. This study will be anchored on the provisions of Derrida's deconstructive criticism.
\end{abstract}

Keywords: Silence, Blindness, Textuality, Existence, Decentring, Tragedy

\section{Introduction}

It is seemingly obvious that blindness correlates with such traits as isolation and loneliness. Isolation, because the sighted individual perceives the blind as obviously separated from his own world - the visualised world. And loneliness, because the perception of demarcation between the world of the blind and the world of the sighted is a threatening gulf that keeps the blind secluded. So, the sighted individual perceives himself as privileged over the blind, since to him the blind does not have equal access with him to the visualized world, the same world in which both share an existence. Hence, there came to exist the socio-cultural categorization of humans as 'privileged' and 'underprivileged,' 'less privileged' or 'handicapped.'

Blindness may yield (or even give rise) to silence. This is another instance of giving blindness a decentred signification, so that in blindness, silence is seen to take residence and/or pre-eminence. The blind is seen as ignorant of the happenings around him and therefore shut out of speech. 'What has he/she seen to comment upon?' may be the question ringing in the mind of the sighted fellow. This is the issue at stake in the mind of Bigger Thomas in Richard Wright's Native Son. Put another way, Bigger Thomas has already seen himself as 'privileged'—not in the sense of social hierarchy, but in the sense of the physical and mental capability of sightedness - over everyone else in the world of Native Son. He begins first by contemplating the literal blindness of Mrs Dalton, and then correlates Mrs Dalton's blindness to the condition of vision of the rest of the characters and, in his thought, concludes that they too are blind.

Considering the line of thought presented in the above paragraphs, we take a look at the argument presented by Miralles(2013) that Native Son provides a more 'psychological' perspective than the likes of its predecessor 'novels like Huckleberry Finn' which 'showed only superficially the oppression of the white over the black' (p. 59). By this argument, Miralles asserts that the psychological perspective of Native Son (and Ellison's Invisible Man) aids the novel to add 'a new point of view: the black's blindness to revolve against his marginal state and his incapability of 
conceiving whites as individuals' (p. 59). Miralles relates the blindness he reads fromNative Sonto racism, and argues that every character in the novel is blind in every sense of the word.

In line with Miralles' position are the arguments of Ayan(2011) and Lowenstein (2013). For Ayan,Native Son is a novel whose business is to highlight emphatically 'the psychological impact of race on African Americans' as well as the harmful effect of 'race logic' on 'white American society' (p. 135); while Lowensteinsees Native Son as 'a heartrending exposé of the racial oppression that permeated Chicago (and the rest of America) during the 1930s' (p. 1).

And then, speaking on the subject of 'blindness', Camp (2014) argues that blindness is a virtue. Seeing the nature in which it has always been presented in literature since the classics, he writes: 'Early writers create a powerful relationship between blindness and wisdom' (p. 4).

Now considering all the preceding arguments, this paper is set to present an analysis of 'blindness' as it relates to the text, approaching the concept from an entirely different perspective: to present Mrs Dalton, the only blind character in the text, as merely metaphorically used to show the blindness of the sighted characters of the text, and to exonerate her from the characterising elements of 'blindness' with which she has always, till present, been associated. In addition to this dimension of thought, this paper will also show the behavioural pattern and impacts of 'silence' in selected characters of the text. This second dimension of thought is arguably an entirely new analytical horizon in relation to the study of Wright's Native Son.

\section{Shades of Silence}

Native Son takes place in a literarykind of worldRicoeur calls a 'possible world' (cited inVerbal Structures p.37), full of sound. This is obviously evidenced in the structural pattern of the text. The opening and the closing expressions of the text are the two walls between which the text is structured - the opening expression being a pre-set exclamation of time to wakefulness and readiness for lively activities, and the closing expression being the involuntary sounds of metals dying out at an unknown distance. They are themselves part of the text, and present the irony of sound. That the text is full of sound ought to depict a world of lively and exuberant activities. But the irony of sound in its presence is the prevalence of silence it is infested with.

The metallic 'Brrrrrriiiiiiiiiiiiiiiiiiiinng' from the alarm clock that opens the text wakes Bigger (and of course the rest of the Thomas family) back to the routineness of their pitiable livelihood. But this very day, Bigger's family are expecting a positive turn around in the pitiable condition of their very existence. They all look up to Bigger as the only one among them through whom their expectations must mature. The pitiable condition of their existence is as depicted in the following extract:

'Turn your heads so I can dress,' she [Bigger's mother] said.

The two boys averted their eyes and gazed into a far corner of the room. The woman rushed out of her nightgown and put on a pair of step-ins. She turned to the bed from which she had risen and called:

'Vera! Get up from there!'

'What time is it, Ma?' asked a muffled, adolescent voice from beneath a quilt.

'Get up from there, I say!'

'O.K., Ma.'

A brown-skinned girl in a cotton gown got up and stretched her arms above her head and yawned. Sleepily, she sat on a chair and fumbled with her stockings. The two boys kept their faces averted while their mother and sister put on enough clothes to keep them from feeling ashamed; and the mother and sister did the same while the boys dressed. (Wright, pp. 33-34)

Their existence has been conditioned thus, and they still feel the discomfort accruing from it. To say they have been silent about their condition would be to lie about them because they have not got any opportunity to get out of the squalor. But they have been living in silence to which they have been subjected by racist fear, what Guthrie calls 'fearhate-fear complex' (cited in Ayan,p.135). They are black, and the condition of their skin colour has subjected them to perpetual fear before the whites who take precedence over them. But they know that they need to (promptly) offset the silence of their very existence and live like "normal" human beings. And now - this day when Bigger is going to take a job at Dalton's - seems to be the right time. Like the prompt offsetting of the nightly silence by the jarring of the metallic sound of the alarm clock which is a pre-set machine, Bigger's mother, sister and brother expect him to offset the silence of their own existence. His mother tells him, 'If you get that job, [...] I can fix up a nice place for you children. You could be comfortable and not have to live like pigs' (p. 41). But Bigger is not mechanically pre-set like the alarm clock; he is human, and thus instinctual.

As an 'instinctual' (Ewen, p.131) being, what Bigger needs is insight (and foresight) to know the right thing to do, the right time for it, and the right manner to approach it. But he has a slightly cunning flaw-his feelings. In place of insight, Bigger is led by his feelings, and therefore wavers to and fro like the pendulum movement of feelings. He relies on his feelings for everything and blames his pitiable condition on the whites who never give him 'a chance' (Wright,pp. 46; 382) at anything. He tells Gus: 'They [the whites] get a chance to do everything' (p. 46). But when he is confronted with the question of what he would want to do if given the chance, he says he would want to do 'nothing' and yet he would want 'to do what other people do':

[Max:] 'What exactly do you want to do?'

[Bigger:] 'Nothing, I reckon. Nothing. But I reckon I wanted to do what other people do.' (p. 382) 
The 'nothing' in Bigger's reply entails his inertia (silence). He does not want to do anything and yet he wants 'to do what other people do.' 'What other people do,' in Bigger's term, is with regard to flying an aircraft (p. 46) or being 'in business' (p. 383). This urge to do 'what other people do' is a negation of inertia. Bigger, in this scenario, therefore stands in what Heidegger calls the 'Between' (Heidegger 1949,p. 312); his character cannot be completely defined as consisting in silence, nor can it be completely defined as set forth in 'rightness' - that which negates and defies the stronghold of silence. Since Bigger is neither inside nor outside the premise of silence, he can be identified as the enigmatic character of Native Son.

The enigma of Bigger's existence is what puts the text forth-heightening the tensions and sustaining the suspense. It is at the forefront of the text's textuality, the point at which the text becomes an 'indecidable' and from which the text proliferates, attaining the point of correlate.

The enigma of the character of Bigger is also realized through the acuteness of his indecision during his conversation with Mrs Dalton who is willing andcapable to help him overturn his inertia:

'How far did you say you went in school, Bigger?' [Mrs Dalton asks.]

'To the eighth grade, mam.'

'Did you ever think of going back?'

'Well, I gotta work now, mam.'

'Suppose you had the chance to go back?'

'Well, I don't know, mam.'

'The last man who worked here went to night school and got an education.'

'Yessum.'

'What would you want to be if you had an education?'

'I don't know, mam.'

'Did you ever think about it?'

'No'm.'

'You would rather work?'

'I reckon I would, mam.' (Wright, p. 92)

Mrs Dalton throws 'a chance' at Bigger. But Bigger's blindness does not allow him the cognizance of the opportunity, and so the opportunity slips away, falling him back to the silence of his being.

Unlike Bigger Thomas, Mrs Dalton's character cannot be construed on the premise of silence. Though already physically blind, she refuses to be classified as completely blind. In her present state, silence does not entail inertia (lack of action); silence entails muteness. Though she may speak with muted voice, she is never silent. But that she speaks up, refusing to be kept mute, is not the criterion for exempting her from the characterisation of silence. The criterion in this case points to the question of 'rightness.' She speaks up at the right time, saying the right thing, and in the right manner.

It is seen from the case of Mrs Dalton that, in Native Son, 'silence' is not an attribute limited only to blacks. To do something (the right thing, of course), whether in deed or in kind, in order to salvage a situation is to be unsilent. The opposite of this, its immediate variant, is to be silent, to be inert. Bigger fails, to a greater degree, to be identified with the criterion of the unsilent individual. His skewness towards silence therefore defines him as a silent character (irrespective of the murder crimes he commits). Mrs Dalton, on the other hand, due to her physical incapacitation in sightedness, cannot do much with action-like forcing Bigger into accepting her help. (But even if she were to 'act,' she would not force Bigger against his will because Bigger is a grown-up.) She has done the much right thing she can by presenting Bigger with the opportunity he needs to be emancipated. She has broken the bounds of silence. Therefore, she must be excused from the indicting attributes of silence.

Mr Dalton, on his own part, holds tenaciously to the old custom of high rent for and segregation against Negroes. In Max's examination of his disposition towards the condition of the livelihood of Negroes, Mr Dalton (unknowingly) makes known the following:

'Now, Mr Dalton, it has been said that you donate millions of dollars to educate Negroes. Why is it that you exact an exorbitant rent of eight dollars per week from the Thomas family for one unventilated, ratinfested room in which four people eat and sleep?'

$[\ldots]$

'Well, there's a housing shortage.' [Mr Dalton replies.]

'All over Chicago?'

'No. Just here on the South Side.'

'You own houses in other sections of the city?'

'Yes.' 
'Isn't it true you refuse to rent houses to Negroes if those houses are in other sections of the city?'

'Why, yes.'

'Why?'

'Well, it's an old custom.' (pp. 356-7)

On the premise of this discourse, it behoves us to make the thetic proposition that Mr Dalton is the most silent of the characters of Native Son. He has observed some of the rudimentary causations of the Negroes' pauperism-the very same condition that results in the Negroes' perpetuation of several crimes - but has refused to dislodge the stronghold of the system. He is the only notable character possessing the power and influence to change the course, but he relents. And unfortunately, his silence costs him the life of Mary, his only daughter and child.

Mr Dalton's silence is equally testified to by Peggy, his house help. Peggy tells Bigger, the same day Bigger resumes work at the Dalton's, that 'Mrs Dalton's the one who's really nice. If it wasn't for her, he [Mr Dalton] would not be doing what he does' (p. 87). Here, 'what he does' refers to the 'millions of dollars' he donates 'to educate Negroes' (p. 356) which he indirectly extorts from them through high rent, and the 'ping-pong tables' he donates to 'the South Side Boys Club' (p. 384) which yield no positive impart to Negroes. And this very little thing he does, which is not imparting after all, remains an eye service even to his maid, which buttresses the point that he is also the miserly character of Native Son. By way of comparison, therefore, Mr Dalton is to blacks what Bigger Thomas is to whites.

Still on the established platform for categorizing characters as silent and unsilent, Jan, Mary and Max must be excused from the premise of silence. Mary, as a white girl and under the watchful eyes of her father Mr Dalton, cannot be expected to 'super-act' her father. She is still dependent on Mr Dalton, and so must tread with caution. But she wants to help Negroes out of their helpless situation. She confesses her support during the drive to Jan's. 'I'm on your side,' she tells Bigger, and then, 'I'm going to meet a friend of mine who's also a friend of yours' (p. 95). She wants to identify with the suffering Negroes, but she has to do so surreptitiously. This is her own way of acting up. And she is taking the right step, only that she is blind to Bigger's feelings as Bigger is blind to her personality.

Jan and Max are described as 'reds' and 'communists.' They suffer as much hate from the whites as do the blacks. However, the difference between them and blacks is 'fear.' Blacks are so engrossed with the fear of whites that they seem comfortable with their silence. The reds are never silent. And what is more? They are ever eager to help the blacks come out of their shell of fear, but they must be subtle in their stratagem. Their strategy is to work on the minds of blacks to get them oriented with their purpose of revolution and Negro emancipation, hence their subtleness.

Max comes into the picture, later, to try to save Bigger from the grave consequence of his crime. But, due to the irrevocability of Bigger's crime and its consequence, Max, irrespective of his combined efforts of faith and action, can do very little for Bigger at the moment. The failure of these combined 'elevated' efforts (of faith and action) bring to limelight the workings of the tragic necessity that has already conditioned Bigger's existence and fate. This awareness is made possible particularly with special regard to the character role of Max who also represents the law, but on the other side of the society's legal pole, so that Bigger's suffering - which results from his own crime but which cannot be abated by any degree of Max's logical reasoning with the law since the crime in turn is blamed on 'the fearful, hopeless existence that he has experienced in a racist society since birth' (Okolie2014, p.11) - becomes associated with tragedy. Max therefore may be associated with blindness in so far as he lacks insight into the very nature of the society in which he lives, or that his act of trying to justify Bigger's criminal disposition gives him away thus. His lack of insight is portrayed through his attempt to save Bigger Thomas from the hungry claws of an already biased society; he is blind to see that this very society cannot understand him.

\section{The Variance of Blindness}

Several critics have argued that Native Son is stuffed with 'blind' characters. None of such arguments exempts any character, black or white, from being categorised as 'blind.' Miralles, for example, argues that every character in Native Son is blind; this is an extension of Giles's argument that 'Mrs Dalton's physical blindness is a metaphor for the absence of insight into black suffering that characterises the limited vision of herself and her husband' (as cited in Miralles, 2013). This paper, as a matter of necessity, seeks to argue against Giles's assertion of Mrs Dalton's blindness.

Holding on still to Giles's provision of the figurative interpretation of blindness as the 'absence of insight,' this paper argues that Mrs Dalton lacks the absence of insight; she is not blind. She is rather a prototype of Oedipus's Teiresias in Sophocles' Oedipus the King, whose physical blindness is a gateway into revelations which manifest through verbal acts of insight. In her physically blind state, Mrs Dalton makes insightful utterances whose traces are linked to the fall or rise of Bigger Thomas (and probably of other Negroes) as well as to the sustenance or damnation of the Dalton's heiress, Mary Dalton. Mrs Dalton's request to her husband, at Bigger's arrival, to put Bigger through the course that would orientate him with his new environment is never to be conceived as ordinary. The wisdom that propels the request (a wisdom to which Mr Dalton is blind) carries with it the power of life and security. To turn it down is to accept the alternate option of death and insecurity, which it warns against. And Mr Dalton, in his characteristic manner of silence and insight-depravity, does not give a second thought in dismissing Mrs Dalton's words. So does he unknowingly yield to the gateway of looming doom: 
'Don't you think it would be a wise procedure to inject him into his new environment at once, so he could get the feel of things?' the woman [Mrs Dalton] asked, addressing herself by the tone of her voice to the man [Mr Dalton] now.

'Well, tomorrow'll be time enough,' the man said hesitantly.

'I think it's important emotionally that he feels free to trust his environment,' the woman said. 'Using the analysis contained in the case record the relief sent us, I think we should evoke an immediate feeling of confidence...'

'But that's too abrupt,' the man said. (Wright, p. 77)

Mrs Dalton, as physically blind as she is, is able to pinpoint the causal factors of her society's dismemberment which Bigger is undoubtedly already affected by, namely, that there is a dividing social line between whites and blacks already rooted deep into the society's political system which has constructed structural fears in the consciousness of blacks among whom Bigger is a spotted victim; and that 'trust' has been maimed on the platform of this racial fear. In her words, therefore, Mrs Dalton is simply making a plea on behalf of both her family and Bigger Thomas. Her plea, conceived in wisdom, is as good as life itself. And if life deferred equates life extinguished, then death must be inevitable. It is ironical, however, that the one who makes the deferment - through the words, 'Tomorrow'll be time enough'-is not the one who receives the immediate penalty for the deferment, though he feels the penalty's pain through the loss of his daughter. So, the weight of the penalty for deferring Mrs Dalton's words is felt throughout the world of Native Son; the penalty consisting in the murders of Mary Dalton and Bessie Mears by Bigger Thomas, the resultant panic that grows and sits among Negroes, and the predicted death of Bigger Thomas.

Mrs Dalton's idea of education is the only tool she can, in her present physical state, offer Bigger for his emancipation. Her insight has granted her the understanding that Negroes' problems have been juxtaposed into one ball of problem, consisting in fear whose abode is the mind. The structural fears Negroes are faced with emanate from their thoughts after being instilled in them by their white counterparts. And it is by purging the mind of this fear that the Negro can be liberated and the looming monstrous consequences of his fear averted. This insight of Mrs Dalton's seems here to be echoing John Newman's assertion of the essence of education as consisting in the production and re-production of knowledge which he calls 'the indispensable condition of expansion of mind' (Newman 1982, p.97).

Mrs Dalton's discussion with her husband is the point of intersection of Bigger's fate with the reality of his personality. Her repetitive request that Bigger be thrust immediately to an affinity with his new environment is suggestive of the insinuation that dire consequences will follow if her words are not heeded. This is a marginalia - a neglected portion of the text, like the biblical 'chief-corner stone' - that on the contrary commands the lure of the text. It is the instance of discourse whose bearing necessitates the happening of Bigger's crime through which Bigger's fate is eventually determined, for had Mr Dalton obliged, Bigger would have commenced the orientation course at once instead of his employment duty, and his course would have been redirected.

To the extent of its consistency, Mrs Dalton's insight is a negation of her physical depravity of sight. She cannot therefore be called 'blind' in the figural sense of the word. To say 'the blind Mrs Dalton' is to merely point to her physical disability, a disability that does not permeate the essence of her being.

\section{The Interweave of Silence and Blindness}

The interweaving of silence and blindness in Bigger Thomas and Mr Dalton proves to be a necessity (whose value cannot afford to be underestimated) for the successful weaving of the text-Native Son. And the same is right to be said about the interlacing of insight and rightness in Mrs Dalton. The meeting of these characters provides the literary friction that enhances the movement of the text as a completed process. It is the necessity of these interlaces that the text requires to be held together, just as the necessity of life requires the placement of opposites on a balance-male and female, good and evil, light and darkness, cold and heat, wealth and poverty, etcetera.

In Bigger lie the spectres of silence and blindness so that, left alone, his actions cannot be weighed on a balance. Bigger's blindness begets his silence, and his silence enhances his blindness in a way that his inertia becomes thrust deeper into the darkness where he merely gropes about in search for the essence of his being. Then there is Mrs Dalton, shinning the light of her insight into the dark realm of Bigger's being, but Bigger's inertia sends Mrs Dalton and her volunteered light to the end of the realm, leaving Bigger still in deeper darkness and heavier inertia. Mrs Dalton's light provides a balance for weighing Bigger's darkness, her insight for Bigger's blindness, her rightness (and aptness) for Bigger's silence.

Mr Dalton, just like Bigger Thomas, has equally been adjudged both blind and silent. And owing to this similarity in terms of silence and blindness, both characters may be seen as different only in their differing skin colours whose presence is well pronounced in the text. Hence, Mr Dalton's whiteness is a balance for weighing Bigger's blackness so that the text's context of racism is wholesomely grasped.

Both (silence and blindness) work hand in hand in Mr Dalton to bring about the tragic necessity of Bigger's end. For Okolie (2014), Bigger is 'compelled by a force he cannot control' (p. 11), a force that denies him 'opportunities and possibilities' and 'constrains his freedom and invariably forces him to take up the struggle to obtain visibility in the world, which continues to blur his identity' (p. 21). This force that 'continues to blur his identity', which here entails blindness, is the beginning of the end to which Bigger Thomas is fated, irrespective of his struggles to avert the fate. And because fate is a tragic necessity that can never be averted, the struggle against it becomes one of the, if not the 
only, fundamental things in tragedy, being the literary form which portrays "personalities who challenge and struggle against relationships "though it might mean ruin"' (Akwanya 2014,p.127). It is on the just presented premise that Native Son must be accounted for as tragedy with such tragic characters as Bigger Thomas, Mary Dalton, and Bessie Mears. It may be a question why Mr Dalton is not included in the list. It is because there is no identifiable struggle (of the kind of struggle that characterises tragedy) with which he can be associated. Among the tragic characters, Bigger Thomas must be regarded as the (failed) tragic hero of Native Son.

\section{Conclusion}

It is the interweave of 'silence' and 'blindness' that holds the lure of the text. These two provide the link for the exposition of the traces of the binaries_-silence and blindness, rightness and insight-in Wright's Native Son. To know 'silence' (in the text) is rather to study it in opposition to what it is; it is to know its other, its binary. And the same is true for 'blindness.'

Bigger Thomas is blind to his immediate needs even when confronted with them by Mrs Dalton. His blindness pulls him down to silence, which we have called 'inertia' in the course of this study. Mary Dalton and Jan, on the other hand, are not identified with silence because of their active involvement in trying to help the Negroes identify and define themselves. But they are blind to Bigger's personality, defined by his 'feelings.' Their blindness then works out the route to Bigger's crime and punishment.

Mr Dalton, on the other hand, is blind and has also been defined as the most silent of the characters in the text because of first, his inability to understand Bigger's psychological disposition upon the latter's arrival to his house and, second, because of his adamant inclination to an 'old custom.'

Finally, it has been established that Native Son is a tragedy as a result of the intersection of silence and blindness, identified in the actions of selected characters of the text.

\section{References}

Akwanya, A.N. (2014).Discourse Analysis and Dramatic Literature. 4th Edition. Enugu: New Generation Books.

Akwanya, A.N. (2011). Verbal Structures: Studies in the Nature and Organisational Patterns of Literary Language. 3rd Edition. Enugu: New Generation Books.

Ayan, Meryem. (2011). 'The Cultural Logic of Racism in Richard Wright's Native Son.' African Journal of History and Culture. Volume 3 Issue 9. pp. 135-139.

Camp, D. (2014). 'Literary Treatment of Blindness from Sophocles to Saramago.' B.A. Thesis. Vanderbilt University.

Ewen, R. B.(2003).An Introduction to Theories of Personality. 6th Edition. New Jersey: Lawrence Erlbaum Associates.

Heidegger, M. (1949). Existence and Being. Illinois: Henry Regnery Company.

Lowenstein, J. (2013, April 25). 'Racialized Blindness in Native Son.'

Miralles, L. (2013). 'Invisibility and Blindness in Ellison's Invisible Man and Wright's Native Son.'

Newman, J. H. C. (1982). The Idea of a University.Indiana: University of Notre Dame Press.

Okolie, M. N. (2014). 'The Discourse of Imposed Identity in IsidoreOkpewho'sCall Me By My Rightful Name and Richard Wright's Native Son.' MA Thesis. University of Nigeria, Nsukka.

Sophocles. Oedipus the King. Trans. F. Storr. (1912). Cambridge: Harvard University Press.

Wright, R. (1940). Native Son. London: Vintage Books. 